\title{
Immigration in Spain: what have we learned from recent evidence?*
}

\author{
Sara de la Rica \\ University of the Basque Country and FEDEA \\ Albrecht Glitz \\ Universitat Pompeu Fabra and Barcelona GSE \\ Francesc Ortega \\ Queens College, CUNY
}

\begin{abstract}
This paper summarizes the recent economics literature on the immigration wave experienced by Spain over the last decade. We survey this growing literature and focus on two key questions: what has been the socio-economic performance of immigrants in Spain and how has immigration impacted the native population. On the former, we conclude that there is evidence of large and highly persistent gaps in the economic performance of immigrants relative to natives in Spain. On the latter, the studies surveyed reveal substantial adaptations in economic choices of Spanish natives in a number of dimensions, including the labor market, household production, schooling, and the housing market.
\end{abstract}

Keywords: immigration, Spain, labor market, housing, schooling, occupations.

JEL codes: J2, J11, J15, J61.

\section{Resumen}

Este artículo revisa la literatura económica reciente sobre la ola de inmigración que ha experimentado España durante la última década. Nuestro análisis de esta amplia literatura se centra en dos preguntas: cuáles han sido los resultados socioeconómicos que han logrado los inmigrantes en España y cómo ha afectado la inmigración a la población nativa. En relación con la primera cuestión, la conclusión es que hay evidencia sobre la existencia de grandes y permanentes diferenciales económicos entre nativos e inmigrantes. Sobre la segunda pregunta, los estudios revisados muestran que, a consecuencia de la inmigración, los españoles han modificado sus comportamientos en múltiples decisiones económicas, incluyendo el mercado de trabajo, las labores domésticas, la escolarización y el mercado de la vivienda.

Palabras clave: inmigración, Spain, mercado laboral, labores domésticas, escolarización, mercado de la vivienda.

Clasificación JEL: J2, J11, J15, J61.

* Parts of this review are closely related to the authors' comprehensive chapter on Immigration in Europe, published in the Handbook of the Rconomics of International Migration (DE LA RICA et al., 2014). 


\section{Introduction}

Over the last few decades several European countries have experienced important immigration episodes. For instance, between 1960 and 2010 the immigrant share increased by roughly 8 percentage points in Germany, Italy and the UK, and by about 10 percentage points in Sweden, as shown by Figure 1. The figure also illustrates the spectacular immigration wave received by Spain in the 10 years between the late 1990s and the late $2000 \mathrm{~s}$, when the immigrant share increased by almost 10 percentage points, peaking at 14.3 percent in $2012^{1}$.

Spain's immigrants arrived from a wide variety of geographic origins. While Romania is currently the main country of origin, followed closely by Morocco, the largest region of origin is South and Central America and, particularly, Ecuador and Colombia, which accounted for over one quarter of Spain's immigrants. Fundamentally, the recent large immigration wave was driven by robust economic growth. Between 1997 and 2007, real GDP grew by more than 3 percent almost every year and the unemployment rate fell from 21 percent to 8 percent (Spanish Statistical Institute) in a context of rising female labor force participation. During this period immigrant employment in construction, services and domestic help rose markedly (Farré et al., 2011, González and Ortega, 2011) ${ }^{2}$. Cultural factors have also played a role in shaping Spain's recent immigration experience. Besides cultural affinity $^{3}$, the large migration from Latin America to Spain can be explained by the special arrangements that allowed citizens of the former colonies to enter the country without a visa (Bertoli et al., 2011, 2013).

The goals of this paper are to review the economics literature that has analyzed the Spanish immigration episode. We focus on two questions. What has been the performance of immigrants, relative to natives, in the Spanish labor market? And what have been the effects of immigration on Spanish natives in the various arenas where natives and immigrants interact. Specifically, we consider the labor market, household production, the housing market, and schooling ${ }^{4}$.

The chapter is structured as follows. Section 2 focuses on immigrants' labor market outcomes. Section 3 reviews the studies that have evaluated the economic effects of immigration. In both cases, we provide a brief methodological review before surveying the relevant work. Section 4 concludes.

\footnotetext{
${ }^{1}$ In absolute numbers the foreign population peaked in Spain in 2009 at close to 5.5 million. Since then it has fallen below 5 million (end of 2012) according to the Population Registry.

${ }^{2}$ Whit the Great Recession and the housing bust, net immigration into Spain fell to zero in 2010 and became negative in 2011 .

3 The important krole of linguistic similarity in shaping international migration flows has been documented by ADSERA and PYTLIKOVA (2012).

4 For brevity we leave out studies that focus on the effects of immigration in other "markets". To name just a few, ALONSO BORREGO et al. (2012) examine the effects on crime, whereas COLLADO et al. (2004) and RODRÍGUEZ PLANAS (2013) focus on consequences for the welfare state. Finally, BENTOLILA et al. (2008) and IZQUIERDO et al. (2010) focus on the effects of immigration on the macroeconomy.
} 
FIGURE 1

\section{IMMIGRANT SHARES IN SELECTED EUROPEAN COUNTRIES}

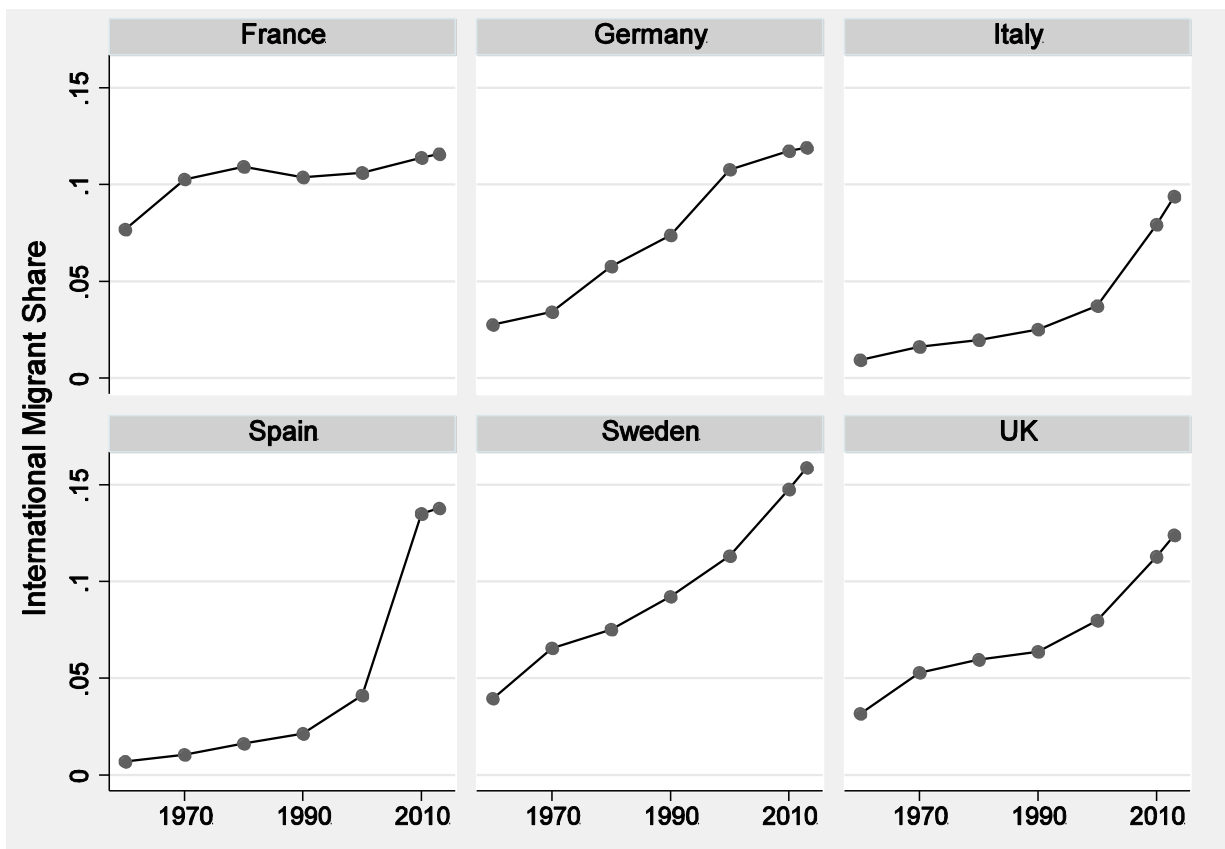

NOTE: This figure shows the share of international migrants in the 6 main immigrant-receiving countries in Europe.

SOURCE: United Nations (2009) for 1960 to 1980, and United Nations (2013) for 1990 to 2013.

\section{Immigrants' Outcomes}

Examining the economic performance of immigrants, relative to natives, is crucial from the point of view of policy-making. Poor performance, manifested in large native-immigrant gaps in economic outcomes, may lead to social exclusion and marginalization, with potentially severe negative externalities. Immigrants' labor market outcomes in their host countries are also crucial in shaping the attitudes of natives towards immigration, which can affect voters' views toward immigration policy.

\subsection{Methodology: Estimation of Native-immigrant Gaps}

Most studies are based on a cross-sectional regression estimated on a sample including both natives and immigrants that relates a particular outcome of interest, such as employment status or log earnings, to an indicator variable for immigrant status. The coefficient associated with this indicator provides a measure of the 
average difference (the gap) in the corresponding outcome between the native and the immigrant population. Typically, such a regression is augmented by including a set of socio-demographic characteristics, such as age, gender, or education, in which case the identified parameter measures a conditional native-immigrant gap. When longitudinal data is available it is common to examine how native-immigrant gaps evolve over time by introducing years since migration as an additional regressor. In this case, the coefficient associated with the immigrant dummy captures the average native-immigrant gap at the time of the immigrant's arrival in the host country while the coefficient associated with the years since migration regressor can be used to assess the speed with which immigrant outcomes converge to those of comparable natives ${ }^{5}$.

Before reviewing the existing empirical evidence, it is informative to provide a crude comparison between the labor market participation and employment rates of natives and immigrants in Spain. As reported by De la Rica et al. (2014), in Spain immigrants exhibit a higher labor force participation rate than natives, which, contrary to most other European host countries, is true not only for male but also for female immigrants. For example, according to the OECD, the labor force participation rate among the working-age population (15-64) in Spain in 2012 amounted to 79.0 percent for native men compared to 85.7 percent for immigrant men, and 66.7 percent for native women compared to 73.4 percent for immigrant women. However, unemployment rates for immigrants are higher than those for natives, and the gap is substantial. For example in 2012, the unemployment rate of native men was 22.4 percent compared to 36.5 percent for immigrant men, and 23.8 percent for native women compared to 32.8 percent for immigrant women (OECD, 2013). Let us now review studies that provide more sophisticated comparisons, which account for covariates such as age, gender, or education, as well as the evolution over time.

\subsection{Gaps in Employment}

Amuedo Dorantes and De la Rica (2007) use 2001 Census data to study the labor market performance of immigrants in Spain. They find that during the first year in the country, the employment gap amounts to 15 percentage points for men and 4 percentage points for women. This gap, however, varies notably depending on country of origin ${ }^{6}$. African men, for example, have an initial employment gap of 8 percentage points. For women, the evidence for Latin American immigrants is

\footnotetext{
${ }^{5}$ In specifications including years since migration and experience, the rate at which the outcomes of immigrants converge to those of comparable natives is given by the coefficient on years since migration plus the difference between the coefficient on experience for immigrants and the analogous coefficient for natives. If the resulting term is positive (negative), there is evidence of convergence (divergence). This argument can easily be extended to specifications that include polynomials in experience and years since migration.

${ }_{6}^{6}$ EU15 immigrants, both men and women, exhibit very large employment gaps relative to native Spaniards, but this is a reflection of many EU15 individuals coming to Spain without the intention to work rather than a difficulty in finding a job.
} 
particularly interesting since already in the first year their employment rate is equal to that of comparable natives ${ }^{7}$. Both for men and women the gaps decrease with time spent in the country and some groups (Latin American women) even display higher employment rates than similar native females five years after arrival in Spain. Similar results are found by Fernandez and Ortega (2007) using the Spanish Labour Force Survey for the period 1996-2006.

\subsection{Gaps in the Quality of Employment: Occupations}

We now examine the average quality of the jobs held by immigrants and comparable natives. We shall conduct this comparison by looking first at differences in the type of occupations held, before turning to gaps in earnings. Amuedo-Dorantes and De la Rica (2007) analyze occupational upgrading in Spain. Ranking occupations by their average wage, these authors estimate ordered probit models to measure the extent to which immigrants upgrade their occupations, relative to natives, as the duration of their stay in the country increases. To start with, they find no evidence of occupational segregation between EU immigrants and natives. In contrast, they report substantial occupational segregation of non-EU immigrants into lowskill occupations in the first few years after arrival. Over time, Eastern Europeans and Latin American immigrants experience an improvement, moving up to better paid occupations, but no such progress is found among Africans. Complementing these findings, Alcobendas and Rodriguez-Planas (2010) report that occupational assimilation in Spain is slower for women and for more educated immigrants.

\subsection{Gaps in the Quality of Employment: Earnings}

The initial earnings of immigrants and their subsequent adjustments in Spain follow a more typical pattern of wage assimilation. Izquierdo et al. (2009) find an initial earnings differential of about 35 percent at the time of arrival, which subsequently decreases for each additional year spent in Spain, reaching about 15 percent after 10 years of residence. After those 10 years, there is no further assimilation. Overall, this assimilation profile is similar for all immigrant groups. Sanromá et al. (2009) provide additional evidence for increasing wages for immigrants as a function of the duration of their stay. According to their cross-sectional estimates, an additional year in Spain increases wages by 1.4 percent. In addition, having legal status is associated with a significant wage premium of around 15 percent. In a complementary study

\footnotetext{
7 DE LA RICA and ORTEGA (2012) report employment rates for women by marital status for different immigrant groups. Their findings reveal similar employment rates for single women regardless of their origin country. However, they find important differences in the size of the marriage employment penalty. Morocco-born females experienced a much larger penalty (about 40 percentage points) than native women ( 5 percentage points) or immigrant females from other origins.
} 
that looks in more detail at the entire wage distribution, Simón et al. (2008) show that legal immigrants from developing countries have lower mean wages and a more compressed wage structure than native-born workers. These differences are largely driven by differences in observable characteristics, and in particular, workplace and occupational segregation.

\subsection{Gaps in Early Human Capital Formation: PISA test scores}

In order to begin to understand the long-run effects of the recent immigration wave it is fundamental to examine the educational outcomes of the children of today's immigrants in Spain. Zinovyevva et al. (2014) study the performance of immigrant children in Spain in the 2006-2009 PISA test scores. They document that immigrant children underperform relative to native children, but their performance improves with time spent in Spain. However, the rate of improvement is not enough to fully catch up. They also find that most of the gap is explained by the socio-economic background of parents.

\section{The Effects of Immigration}

What are the economic effects of immigration on the receiving countries? This important question is at the heart of much of the policy debate surrounding immigration and has motivated extensive research. We review recent work that has examined the effects of immigration on market outcomes, and the implications for the native population, in a variety of contexts: the labor market, household production, schooling, and the housing market.

\subsection{The Labor Market: Wages and Employment}

The goal of this section is to outline the usual methodological approaches to measure the labor market effects of immigration as well as a concise review of the recent empirical evidence. We survey studies that have focused on a variety of outcomes: employment, wages, occupation choice, and industry composition.

When thinking about the labor market impact of immigration, labor economists have typically assumed that the main mechanism through which the host country's labor market adjusts to immigrant inflows are changes in factor prices, in particular changes in skill-specific wages. In a simple one-good neoclassical economy, the factor proportions approach postulates that as long as immigrants differ in their skill composition from the existing labor force in the host country, their arrival will lead to changes in the relative supplies of different skill groups and, in turn, to changes in 
relative wages ${ }^{8}$. If the native labor supply is elastic or if wages are rigid, there may also be adjustments in native employment. Early work on the labor market effects of immigration focused on testing these predictions.

\section{- Empirical Methodologies}

The spatial correlation approach (Altonji and Card, 1991; Borjas et al., 1997) consists of estimating regression equations, either in levels or first differences, in which the dependent variable is the average outcome (typically wages or employment rates) in a region, and the main explanatory variable is the foreign-born share in that same region. This approach exploits variation in the immigrant density across regions to identify the causal effects of immigration. The basic idea is that native wages (or employment rates) may be lower in regions with more immigrants or, in the first differences specification, in regions that have received a larger inflow of immigrants.

This strategy faces two important econometric challenges: first, it is likely that the location decisions of immigrants respond to region-specific shocks that are unobservable to the researcher. The presumption is that immigrants tend to choose regions experiencing positive labor demand shocks, which will tend to generate an upward bias in OLS estimates of the effect of immigration on native wages and employment rates. Secondly, cities and regions are not isolated entities. As a result, immigration into one region may trigger labor outflows or capital inflows. If not accounted for, these compensating flows are likely to exacerbate the bias in OLS estimates ${ }^{9}$.

Besides a few scarce quasi-natural experiments which we will discuss later on, the most common way to tackle the endogeneity concerns has been to exploit the tendency of immigrants to locate in cities and regions in which individuals from their own country of origin are already present (Bartel, 1989; Munshi, 2003). Altonji and Card (1991) and Card (2001) developed an instrumental-variables strategy based on this idea, which has subsequently been used by many authors in a variety of contexts. Regarding the compensating inter-regional factor flows, some aspects have been addressed relatively convincingly, while others remain still unanswered. Card and DiNardo (2000), Card (2009), Wozniak and Murray (2012), and others have shown that when a city receives an inflow of unskilled immigrants, its total unskilled labor force (including both natives and immigrants) increases roughly one

\footnotetext{
${ }^{8}$ In the short run it is also possible that immigration will reduce capital intensity and, hence, the average wage in the economy. As the capital-labor ratio returns to its steady-state level, this effect should disappear. In integrated markets such as the European Union, capital flows relatively freely and, as a result, the capital supply may be almost perfectly elastic even in the short run.

${ }^{9}$ AYDEMIR and BORJAS (2011) have argued that attenuation bias due to measurement error could be an additional problem, biasing OLS estimates toward zero.
} 
for one ${ }^{10}$. Much less evidence exists regarding the inter-regional mobility of firms and capital in response to immigration. Olney (2013) finds that immigration into a city leads to an increase in the number of establishments as well as the size of the existing ones. Along these lines, Beaudry et al. (2011) find evidence that the number of entrepreneurs and, more generally, the demand for labor in a city is proportional to the size of the local population.

The second widely used empirical methodology to study the labor market impact of immigration is the structural skill-cell correlation approach proposed by Borjas $(2003)^{11}$. Central to this approach is the assumption that the production process in a host country's economy can be reasonably well described by a nested constant elasticity of substitution (CES) production function which, on the highest level, combines labor and capital to produce a single aggregate output good. In the original application, Borjas (2003) models the overall labor input as a CES-aggregate of education-specific labor inputs that are, in turn, CES-aggregates of education-andexperience-specific labor inputs. The key parameters in this production structure are the elasticities of substitution governing each nest. These parameters are estimated as follows. First, workers are assigned to skill cells based on observed formal education and potential work experience. The elasticity of substitution between different education-experience groups is identified by regressing the average wage in each skill-cell on the supply of workers (in logs) in that same cell and fixed effects dictated by the theoretical marginal product equation. Using the estimated elasticity (and estimated fixed effects), we can then aggregate to compute the labor composite at the immediate higher level, that is, education groups. Again, the elasticity of substitution across the (education) groups in this nest will be identified by regressing average wages on the size of the labor composite in that same cell, along with the required fixed effects. After these estimations, the fully parameterized production function can then be used to simulate the wage effects of an immigration flow with any desired size and composition, taking into account the full set of own- and cross-factor price elasticities. By carrying out the analysis at the national level, the structural skill-cell correlation approach alleviates the concerns about offsetting labor and capital flows across regions that complicate the identification of the wage effects of immigration in the spatial correlation approach.

10 Not all studies reach this conclusion. BORJAS (2006), for example, finds that immigration into a local labor market is associated with a lower in-migration rate, a higher out-migration rate, and a decline in the growth rate of the native workforce. For Italy, MOCETTI and PORELLO (2010) find evidence that immigration into a region may have reduced the inflows of low-skilled natives and increased the inflows of highly skilled natives. PERI and SPARBER (2011) discuss the role of inherent model bias in the estimation of these immigrant-native displacement effects.

${ }_{11}$ Besides the structural approach presented here, which extends earlier factor proportions approaches in the literature (e.g. BORJAS et al., 1992), BORJAS (2003) also estimates reduced-form regressions relating the nationwide average wage in a given skill cell (defined by education and experience) to the corresponding nationwide share of immigrants in that same skill cell, controlling for secular changes in the wage profiles of different education and experience groups by including a comprehensive set of fixed effects. 
Manacorda et al.(2012) and Ottaviano and Peri (2012) point out that the framework in Borjas (2003) assumes perfect substitutability between natives and immigrants with the same observed levels of formal education and potential experience. In order to test this assumption, these authors add one more level to the production function by allowing labor in a given experience-education cell to be a CES aggregate of native and immigrant workers, governed by an additional elasticity of substitution that needs to be estimated as well. As we discuss below, this seemingly minor extension has important implications for the assessment of the labor market impact of immigration and has motivated several studies in the European context.

Although seldom discussed, the skill cell correlation approach is not free of endogeneity concerns either ${ }^{12}$. First, immigrants in a particular experience-education cell endogenously choose their destination country. While this may be less relevant for the case of the U.S., it is certainly important in the context of Europe, where countries are geographically much closer together and barriers to internal labor mobility are practically non-existent. As a result, the observed immigrant inflows into specific skill cells may be driven by economic conditions, rendering them endogenous and potentially biasing the estimates of the associated elasticities of substitution. Second, immigration quotas and the enforcement of immigration laws often, whether explicitly or implicitly, depend on labor market conditions in the host country (Hanson and Spilimbergo, 2001; Fasani, 2010), creating a direct link between observed inflows into given skill cells and economic conditions. Third, the basic skill cell correlation approach ignores the fact that natives and immigrants with the same observable skills often work in very different occupations (Steinhardt, 2011) and regional labor markets with potentially large differences in wage levels and other relevant characteristics ${ }^{13}$. This affects the degree of their substitutability with native workers, a point also raised by Dustmann and Preston (2012) who show that estimated elasticities of substitution between immigrants and natives are systematically affected by the skill downgrading experienced by recently arrived immigrants.

Besides the spatial correlation approach and the skill-cell correlation approach, a third methodology attempts to exploit events that can be reasonably considered as natural experiments to identify the labor market impact of immigration. In an ideal experimental setting, differently sized immigration flows would be randomly assigned to different markets, thus circumventing the inherent endogeneity of immigrant location choices. Not surprisingly, given the nature of the question, most applications to date fall somewhat short of this perfect setting, and should therefore more appropriately be characterized as quasi-experiments. The seminal study in this

12 BORJAS (2003) acknowledges the potential for endogeneity bias. FELBERMAYR et al. (2010) discuss these identifying assumptions in detail. Our discussion here draws heavilyon their paper.

13 LLULL (2010) has extended this framework to allow for endogenous decisions on education, labor market participation and occupation choice. The paper presents the results of a structural estimation for a sample of Census-based U.S. data. His findings reveal a fair amount of adjustment along these margins, together with a significant residual effect on the wages of natives. 
literature is Card's (1990) Mariel boatlift study, which exploits a particular episode of Cuban emigration to the United States in $1980^{14}$. While a number of European studies have exploited quasi-experiments to assess the labor market impact of immigration (Angrist and Kugler, 2003, using the war in Yugoslavia; Hunt, 1992, using the repatriation of Algerians to France in the early 1960s; and Glitz, 2012, using the return of ethnic Germans after the fall of the Berlin wall), there is presently no such analysis available for Spain.

\section{- Findings in the Literature}

The first paper to investigate the labor market effects of the recent wave of immigration received by Spain was Carrasco et al. (2008). These authors adopt the skill cell correlation approach and use data from the 1991 and 2001 Population Censuses and the 2002 Survey of Earnings Structure, thus only covering the first part of the immigration episode. The main finding of this study is that increases in the foreign-born share in a skill cell are negatively associated with employment and wage growth. However, the estimated magnitudes are small and the effects not very robust, leading the authors to conclude that there were no economically significant effects on natives' employment and wages. Gonzalez and Ortega (2011) adopt instead the spatial correlation approach (coupled with the ethnic network instrument) and combine data from the Labor Force Survey for the years 2001-2006 with social security wage records and data from the population registry. Their instrumental variables estimates reveal no evidence of detrimental effects of immigration on native wages or employment rates, a result in line with the findings in AmuedoDorantes and De la Rica (2011).

- Sectoral Composition and Endogenous Technology Adoption

Faced with the recurring finding of a lack of adjustments in relative wages and employment in response to immigrant inflows, economists were forced to consider potential alternative adjustment channels and initially turned to international trade theory for explanations. Using U.S. data, Lewis (2003) provides the first formal test of the classical Rybczynski theorem according to which a small open economy may respond to an increase in the supply of, say, unskilled labor by expanding employment and output in unskilled-intensive industries while leaving relative factor intensities and factor prices unaffected ${ }^{15}$. Building on this study, Gonzalez and Ortega (2011) systematically test the predictions of the Rybczynski hypothesis in the Spanish context.

\footnotetext{
14 For a critical review of this event as a natural experiment, see ANGRIST and KRUEGER (1999).

15 HANSON and SLAUGHTER (2002) and GANDAL et al. (2004) pioneered the analysis of immigration through the lens of the small open economy model.
} 
After showing that relative wages do not respond to immigrant inflows in Spain, they proceed by providing comprehensive evidence that regional economies absorb immigration flows primarily through within-industry adjustments in relative factor intensities rather than between-industry adjustment as predicted by the Rybczynski theorem. That is, an increase in the local supply of, say, unskilled labor leads to an increase in the relative use of unskilled labor in production. The fact that such adjustments in relative factor intensities are not accompanied by changes in relative wages strongly points towards endogenous changes in production technologies as an alternative mechanism through which local economies can absorb immigrationinduced changes in local labor supply. Accordingly, if an inflow of immigrants that increases the local availability of unskilled labor induces firms to switch toward production technologies that are more intensive in unskilled labor, then the resulting change in the relative unskilled wage will be mitigated ${ }^{16}$.

\section{- Occupational and Task Specialization}

The expectation that immigration should reduce the wages of native workers with similar skill levels relies on the implicit assumption that these workers are perfect substitutes in production. As we outlined earlier, there is a growing literature attempting to estimate the degree of substitution between observationally equivalent natives and immigrants. Peri and Sparber (2009) have investigated the micro-foundations for this mechanism. They hypothesized that native workers have a comparative advantage in communication-intensive tasks (as opposed to manual tasks), relative to recent immigrants. As a result, natives and immigrants with the same observable skills (education and potential experience) will specialize in different occupations, reducing the degree of labor-market competition between the two groups. AmuedoDorantes and De la Rica (2011) investigate this mechanism for Spain, using data from the Spanish Labor Force Survey for the period 2000-2008. Their findings provide strong support for the occupational specialization hypothesis. Additionally, these authors explore the role played by language proficiency in explaining immigrant specialization patterns. They find that immigrants from Spanish-speaking countries specialize in more communication-intensive occupations than other immigrant groups, providing further support for the hypothesis of task specialization based on comparative advantage ${ }^{17}$.

${ }^{16}$ Such technology shifts may be driven by directed technical change as suggested by ACEMOGLU (2002) or by producers' optimal choice of production technologies from a given pool of alternatives as suggested by, for example, BEAUDRY and GREEN (2003) and CASELLI and COLEMAN (2006). Several studies provide empirical evidence of the connection between the composition of the labor force at the local level and technology adoption. For instance, LEWIS (2011) finds that the use of automation machinery indeed expands more rapidly in areas with faster growth in the relative supply of skilled labor, and BEAUDRY et al. (2010) show that local skill abundance leads to a faster adoption of new technologies.

${ }^{17}$ Using attitudinal data, ORTEGA and POLAVIEJA (2012) show that Europeans employed in manualintensive occupations (and thus more exposed to labor-market competition from immigrants) are less in favor of immigration than other natives with the same levels of education. These findings based on attitudinal data are also consistent with the occupational specialization hypothesis. 


\subsection{Household Production}

Another important channel through which immigration may affect the well-being of the native population is by reducing the prices of non-traded services such as child care, elderly care and household chores. By effectively increasing their purchasing power, cheaper services may benefit native households and lead to reorganizations of household production with consequences for the labor supply of the (highly skilled) natives that rely on these services.

The pioneering study in this literature is Cortes (2008) who finds that low-skill immigration in the U.S. leads to a reduction in the prices of household services such as housekeeping and gardening. By making these services more affordable, (unskilled) immigration may allow skilled natives to increase their labor supply. Further probing this mechanism, Cortes and Tessada (2011) find that low-skilled immigration leads to an increase in hours worked by highly educated women in the U.S. along with corresponding reductions in the time devoted to household work. As a result of the higher labor market attachment of skilled (female) workers, the overall change in the relative supply of skilled to unskilled labor triggered by unskilled immigration may be mitigated, contributing to explain the apparent lack of response of natives' wages to immigration ${ }^{18}$. Farré et al. (2011) follow the approach of Cortes and Tessada (2011) and find that female immigration to Spain has increased the local availability of household services and reduced their prices. By allowing skilled native women to return to work earlier after childbirth and to continue working while caring for elderly dependents, immigration is estimated to account for one third of the recent large increase in the employment rates of college-educated women in Spain.

\subsection{Housing Market}

Coinciding with the immigration wave, Spain experienced a pronounced boom in housing prices and construction. While this was to some extent a global phenomenon, the housing boom in Spain displayed an unusual intensity. As documented by Gonzalez and Ortega (2013), between 1998 and the peak of the boom in 2008, housing prices in Spain increased by 175 percent. In comparison, house prices in the US increased by 104 percent between the peak in 2007 and ten years earlier. The large increase in housing prices in Spain is even more striking when we take into account the intense residential construction activity during the same period. Between 1998 and 2008, the share of construction in Spain's GDP increased by four percentage points, reaching 10.7 percent in 2008 . The annual flow of new dwellings built increased from below 250,000 units in 1998 to 600,000 units a year at the peak between 2006 and 2008 .

18 CORTES and PAN (2012) find similar results using data for Hong Kong, where hiring foreign domestic workers is a very prevalent phenomenon. 
Starting in 2008, the housing market in Spain plummeted. Average housing prices and the annual flow of housing units have fallen rapidly since then.

In their study Gonzalez and Ortega (2013) attempt to isolate the role played by immigration in accounting for the housing boom in Spain. Naturally, one would expect that the large population increase fuelled by immigration increased the demand for housing, directly through purchases or through the rental market, which may have contributed to the increase in housing prices and quantities. Methodologically, their paper is closely related to the literature studying the causal effects of immigration on housing prices and rents in the US using a spatial correlations approach. Saiz (2007) estimates the effects of immigration on housing prices and rents in US metropolitan areas. According to his instrumental variables estimates, an immigration flow that increases population by one percent leads to a 1 percent increase in rents and a 3 percent increase in house prices. Ottaviano and Peri (2007) investigate empirically the effects of immigration on the labor and rental markets using data for US states. Their estimates suggest that the rent-elasticity of immigration is around 0.7, and between 1 and 2 for housing prices. In a recent study, Bohn et al. (2011) study the effects of Arizona's LAWA law on the size of the low-educated, male Hispanic population as well as on the housing rental market. Their results suggest that outmigration reduced the demand for rental housing, substantially increasing rental vacancies.

The main finding in Gonzalez and Ortega (2013) is that immigration led to sizeable increases in both the price of housing and construction activity in Spain. Specifically, their estimates imply that between 2000 and 2010, immigration led to an average 1.5 percent annual increase in the working-age population, which in turn led to an annual increase in housing prices of about 2 percent, and a 1.2 to 1.5 percent increase in housing units. Overall, immigration was responsible for about one quarter of the increase in prices and about half of the construction activity over the decade.

\subsection{Schools}

A number of recent studies have examined the effects of immigration on the schooling choices of native households, with a focus on the decision to enroll their children in a public school or in a (tuition-based) private school. This decision has important long-term consequences because it ultimately shapes the political support for the resources devoted to public education.

Several authors have analyzed empirically what the effects of immigration for the schooling decisions of natives are, often in the context of the United States, and found evidence of a displacement of natives away from tuition-free public schools and toward private schools. Betts and Fairlie (2003) found that increases in the share of immigrants in a metropolitan area were associated with increases in the probability to attend private school among native households in California. Complementing the previous study, Cascio and Lewis (2012) found evidence of native migration to 
other school districts (within a metropolitan area) in response to inflows of Hispanic students with low English proficiency. Several authors have also found evidence of native displacement or immigrant segregation in schools in Europe. Kristen (2008) provides evidence for Germany, Gerdes (2010) for Denmark, and Schneeweis (2013) for Austria.

In the context of Spain, Anghel and Cabrales (2010) study the roles of schools and parental background in standardized exams in Spain. Confirming previous studies, they find that parental background plays an important role. They also document important heterogeneity across children of different ethnic backgrounds, even after controlling for the parents' socio-economic status. However, they do not find evidence of a significant effect of class size or performance differences between public and "concerted" (private but subsidized) schools, once parental background is controlled for. Farré et al. (2014) empirically analyze the effects of immigration on the schooling decisions of native households in Spain using household-level data for years 2000-2012, a period characterized by a large immigration wave and a severe recession. Their estimates reveal that Spanish households responded to immigration by increasing their educational expenditures, driven by an important native flight from tuition-free schools toward private ones. They also find that immigration led to large and significant increases in student-teacher ratios in public schools, probably reducing quality. Finally, their analysis also offers strong evidence of a creamskimming effect: only the more educated native households switched to private schools in response to immigration. Overall their results suggest that the reduction in household income due to the Great Recession mitigated the flight toward private schools but was not enough to fully offset it.

Coen-Pirani (2011) addresses this question from a political-economy perspective. He analyzes the effects of the large immigration wave experienced by California between 1970 and 2000 on the schooling choices of households and on the voting equilibrium that determines the funding and quality of public education. His counterfactual analysis suggests that immigration may have been responsible for a 24 percent reduction in the quality of public education, measured by spending per student in public schools, along with a reduction in the share of native students enrolled in public schools in California. Inspired by this work, Tanaka et al. (2014) extend the model by Coen-Pirani (2011) and adapt it to the analysis of immigration in Spain. Importantly, their framework incorporates the fact that the vast majority of private schools in Spain are heavily subsidized by the government ("concerted" schools), and they distinguish between the direct effect of the arrival of immigrants and the political effect once these immigrants gain the right to vote. By means of simulations they obtain the following two main findings. First, the combined effects of immigration and naturalization will lead to a small increase in the overall size of public education as measured by enrollment.

However, this increase in size masks an important composition effect. There is a large reduction in the enrollment of native students in public schools (who flee toward private schools), which is offset by the arrival of a large number of immigrants who 
are characterized by a much higher propensity than natives to attend public schools. Secondly, their analysis predicts a large reduction in the quality of public education as measured by per capita spending, of perhaps up to 10 percent. According to their results, these effects will unfold unevenly over time. While the changes in the size and student composition of public schools will take place promptly upon arrival of the immigrants, the reduction in funding will be more gradual and only fully take place once the immigrant population has been enfranchised.

\section{Conclusions}

This chapter has reviewed the economic research devoted to the recent Spanish immigration experience. We briefly state our conclusions. In terms of the economic performance of immigrants in Spain, most studies find only moderate employment gaps between immigrants and natives, with somewhat larger gaps for men and during the first few years after arrival, and with significant heterogeneity across source countries.

In contrast, wage gaps are relatively large even after prolonged residence in Spain, with estimates putting them at 35 percent at the time of arrival and 15 percent after ten years of residence. In a more long-term perspective, it has also been documented that immigrant children obtain significantly worse test scores than native children, mainly reflecting their lower socio-economic background.

Turning to the effects of immigration on the economic outcomes of natives, we find a variety of ways in which the native population responded to immigration flows, mitigating the head-to-head competition and downward pressure on the wages of natives. In the labor market, immigration led to an increase in occupational specialization, with natives and Spanish-speaking immigrants further specializing in occupations that are intensive in communication tasks.

Some authors have also documented that immigration has led to changes in household production and, in particular, have found that skilled native females increased their labor supply in response to the greater availability of household services provided by immigrants. Finally, there is also evidence for important changes in the schooling choices of natives in response to immigration. Specifically, native households of higher socio-economic status responded by making a greater use of private schools than was formerly the case. This is an important finding since it suggests that the political support for a well-funded public education may be eroded over time, with potentially very adverse consequences in terms of economic inequality and upward mobility. 


\section{References}

[1] ACEMOGLU, D. (2002): "Directed Technical Change", Review of Economic Studies, vol. 69, no. 4, pp. 781-809.

[2] ADSERA, A. and M. PYTLIKOVA (2012): "The Role of Language in Shaping International Migration”, CReAM Discussion Paper Series 1206.

[3] ALCOBENDAS, A. and N. RODRÍGUEZ PLANAS (2010): "Immigrants' Assimilation Process in A Segmented Labor Market", UFAE and IAE Working Papers 822.10.

[4] ALONSO BORRREGO, C.; GAROUPA, N. and P. VÁZQUEZ (2012): "Does Immigration Cause Crime? Evidence from Spain", American Law and Economics Review, 14 (1), pp. 165-191.

[5] ALTONJI, J. G. and D. CARD (1991): "The Effects of Immigration on the Labor Market Outcomes of Less-skilled Natives", in John M. Abowd and Richard B. Freeman (eds.), Immigration, Trade, and the Labor Market, pp. 201-234. Chicago: University of Chicago Press.

[6] AMUEDO DORANTES, C. and S. DE LA RICA (2007): "Labour Market Assimilation of Recent Immigrants in Spain”, British Journal of Industrial Relations, vol. 45 (2), pp. 257-284.

[7] AMUEDO DORANTES, C. and S. DE LA RICA (2011): "Complements or Substitutes? Task Specialization by Gender and Nativity in Spain”, Labour Economics, vol. 18 (5), pp. 697-707.

[8] ANGHEL, B. and A. CABRALES (2010): "The Determinants of Success in Primary Education in Spain", FEDEA Working Papers No. 2010-20.

[9] ANGRIST, J. and A. KRUEGER (1999): “Empirical Strategies in Labor Economics," in The Handbook of Labor Economics, edited by O. Ashenfelter and D. Card, Chapter 23, Volume III, North Holland.

[10] ANGRIST, J. and A. KUGLER (2003): "Protective or Counterproductive? Labour Market Institutions and the Effect of Immigration on EU Natives", Economic Journal, vol. 113 (488), F302-F331.

[11] AYDEMIR, A. and G. J. BORJAS (2011): "Attenuation Bias in Measuring the Wage Impact of Immigration", Journal of Labor Economics, vol. 29 (1), pp. 69-113.

[12] BARTEL, A. P. (1989): "Where Do the New U.S. Immigrants Live?", Journal of Labor Economics, vol. 7 (4), pp. 371-391.

[13] BEAUDRY, P.; DOMS, M. and E. G. LEWIS (2010): "Should the Personal Computer be Considered a Technological Revolution? Evidence from U.S. Metropolitan Areas", Journal of Political Economy, vol. 118 (5), pp. 988-1036.

[14] BEAUDRY, P. and D. A. GREEN (2003): "Wages and Employment in the United States and Germany: What Explains the Differences? American Economic Review, vol. 93 (3), pp. 573-602.

[15] BEAUDRY, P.; D. A. GREEN and B. SAND (2011): "How Elastic is the Job Creation Curve?". Working Paper, University of British Columbia.

[16] BENTOLILA, S.; DOLADO, J. J. and J. JIMENO (2008): "Does Immigration Affect the Phillips Curve? Some Evidence for Spain”, European Economic Review, vol. 52 (8), pp. 1398-1423.

[17] BERTOLI, S.; FERNÁNDEZ HUERTAS, J. and F. ORTEGA (2011): "Immigration Policies and the Ecuadorian Exodus", The World Bank Economic Review, vol. 25 (1), pp. 57-76. 
[18] BERTOLI, S.; FERNÁNDEZ HUERTAS, J. and F. ORTEGA (2013): "Crossing the Border: Self-selection, Earnings, and Individual Migration Decisions”, Journal of Development Economics, vol. 101, pp 75-91.

[19] BETTS, J. R. and R. W. FAIRLIE (2003): "Does Immigration Induce Native Flight from Public Schools into Private Schools?”, Journal of Public Economics, vol. 87 (5-6), pp. 987-1012.

[20] BOHN, S.; LOFSTROM, M. and S. RAPHAEL (2011): “Did the 2007 Legal Arizona Workers Act Reduce the State's Unauthorized Immigrant Population?”, forthcoming Review of Economics and Statistics.

[21] BORJAS, G. J. (2003): “The Labor Demand Curve Is Downward Sloping: Reexamining the Impact of Immigration on the Labor Market", Quarterly Journal of Economics, 118 (4), pp. 1335-1374.

[22] BORJAS, G. J. (2006): "Native Internal Migration and the Labor Market Impact of Immigration", Journal of Human Resources, vol. 41 (2), pp. 221-258.

[23] BORJAS, G. J.; FREEMAN, R. B. and L. F. KATZ (1992): “On the Labor Market Effects of Immigration and Trade", in G. J. Borjas and R.B. Freeman (eds.), Immigration and the Work Force: Economic Consequences for the United States and Source Areas, pp. 213-244, Chicago, IL: National Bureau of Economic Research, University of Chicago Press.

[24] BORJAS, G. J.; FREEMAN, R. B. and L. F. KATZ (1997): “How Much Do Immigration and Trade Affect Labor Market Outcomes?", Brookings Papers on Economic Activity, vol. 28 (1), pp. 1-90.

[25] CARD, D. (1990): "The Impact of the Mariel Boatlift on the Miami Labor Market", Industrial and Labor Relations Review, Vol. 43 (2), pp. 245-257.

[26] CARD, D. (2001): "Immigrant Inflows, Native Outflows, and the Local Labor Market Impacts of Higher Immigration", Journal of Labor Economics, vol. 19 (1), pp. 22-64.

[27] CARD, D. (2009): "How Immigration Affects U.S. Cities", in Urban Enigma: City Problems, City Prospects, edited by R. P. Inman, Princeton University Press.

[28] CARD, D. and J. DINARDO (2000): “Do Immigrant Inflows Lead to Native Outflows?”, American Economic Review Papers and Proceedings, vol. 90 (2), pp. 360-367.

[29] CARRASCO, R.; JIMENO, J. F. and A. C. ORTEGA (2008): "The Effect of Immigration on the Labor Market Performance of Native-born Workers: Some Evidence for Spain", Journal of Population Economics, vol. 21 (3), pp. 627-648.

[30] CASCIO, E. U. and E. G. LEWIS (2012): "Cracks in the Melting Pot: Immigration, School Choice, and Segregation", American Economic Journal: Economic Policy, vol. 4 (3), pp. 91-117.

[31] CASELLI, F. and W. J.COLEMAN (2006): “The World Technology Frontier", American Economic Review, vol. 96 (3), pp. 499-522.

[32] COEN PIRANI, D. (2011): "Immigration and Spending on Public Education: California, 1970-2000”, Journal of Public Economics, vol. 95 (11), pp. 1386-1396.

[33] COLLADO, M. D.; ITURBE ORMAETXE, I. and G. VALERA (2004): “Quantifying the Impact of Immigration on the Spanish Welfare State", International Tax and Public Finance, vol. 11 (3), pp. 335-353.

[34] CORTES, P. (2008): “The Effect of Low-skilled Immigration on US Prices: Evidence from CPI Data”, Journal of Political Economy, vol. 116 (3), pp. 381-422. 
[35] CORTES, P. and J. PAN (2012): "Outsourcing Household Production: The Demand for Foreign Domestic Helpers and Native Labour Supply in Hong Kong”, Journal of Labor Economics, Vol. 31 (2).

[36] CORTES, P. and J. TESSADA (2011): "Low-skilled Immigration and the Labor Supply of Highly Skilled Women", American Economic Journal: Applied Economics, vol. 3 (3), pp. 88-123.

[37] DE LA RICA, S.; GLITZ, A. and F. ORTEGA (2014): "Immigration in Europe: Trends, Policies and Empirical Evidence", in Handbook of the Economics of International Migration, edited by B. R. Chiswick and P. Miller, Elsevier, forthcoming.

[38] DE LA RICA, S. and F. ORTEGA (2012): "Cultural Integration in Spain”, Chapter 5 in Cultural Integration of Immigrants in Europe, edited by Algan, Y, Bisin, A., Manning, A., and T. Verdier, Oxford University Press, pp. 148-171.

[39] DUSTMANN, C. and I. PRESTON (2012): "Comment: Estimating the Effect of Immigration on Wages", Journal of the European Economic Association, vol. 10 (1), pp. 216-223.

[40] FARRÉ, L.; M. BOSCH and M.A. CARNERO (2011): "Rental Housing Discrimination and the Persistence of Ethnic Enclaves", IZA Discussion Paper No. 5583.

[41] FARRÉ, L.; GONZÁLEZ, L. and F. ORTEGA (2011): "Immigration, Family Responsibilities and the Labor Supply of Skilled Native Women", The B.E. Journal of Economic Analysis \& Policy, vol. 11 (1), Article 34.

[42] FARRÉ, L.; ORTEGA, F. and T. RYUICHI (2014): "Immigration and School Choices in the Midst of the Great Recession", Mimeo CUNY.

[43] FASANI, F. (2010): "Deporting Undocumented Immigrants: the Role of Labor Demand Shocks", Mimeo.

[44] FELBERMAYR, G.; W. GEIS and W. KOHLER (2010): "Restrictive Immigration Policy in Germany: Pains and Gains Foregone?", Review of World Economics, vol. 146 (1), pp. 1-21.

[45] FERNANDEZ, C. and C. ORTEGA (2007): "Labor Market Assimilation of Immigrants in Spain: Employment at the Expense of Bad Job-Matches?", Spanish Economic Review, vol. 10 (2), pp. 83-107.

[46] GANDAL, N.; G. H. HANSON and M. J. SLAUGHTER (2004): “Technology, Trade, and Adjustment to Immigration in Israel", European Economic Review, vol. 48 (2), pp. 403-428.

[47] GERDES, C. (2010): “Does Immigration Induce 'Native Flight' from Public Schools? Evidence from a Large Scale Voucher Program", IZA Discussion Papers No. 4788.

[48] GLITZ, A. (2012); “The Labor Market Impact of Immigration: A Quasi-Experiment Exploiting Immigrant Location Rules in Germany", Journal of Labor Economics, vol. 30 (1), pp. 175-213.

[49] GONZÁLEZ, L. and F. ORTEGA (2011): "How Do Very Open Economies Absorb Large Immigration Flows? Recent Evidence from Spanish Regions", Labour Economics, vol. 18 (1), pp. 57-70.

[50] GONZÁLEZ, L. and F. ORTEGA (2013): "Immigration and Housing Booms: Evidence from Spain", Journal of Regional Science, vol. 53 (1), pp. 37-59.

[51] HANSON, G. H. and M. J. SLAUGHTER (2002): "Labor-market Adjustment in Open Economies: Evidence from U.S. States”, Journal of International Economics, vol. 57 (1), pp. 3-29. 
[52] HANSON, G. H. and A. SPILIMBERGO (2001): "Political Economy, Sectoral Shocks, and Border Enforcement", Canadian Journal of Economics, vol. 34 (3), pp. 612-638.

[53] HUNT, J. (1992): "The Impact of the 1962 Repatriates from Algeria on the French Labor Market", Industrial and Labor Relations Review, vol. 45 (3), pp. 556-572.

[54] IZQUIERDO, M.; LACUESTA, A. and R. VEGAS (2009): “Assimilation of Immigrants in Spain: A Longitudinal Analysis”, Labour Economics, vol. 16 (6), pp: 669-678.

[55] IZQUIERDO, M.; JIMENO, J. F. and J. A. ROJAS (2010): "On the Aggregate Effects of Immigration in Spain", SERIEs, vol. 1 (4), pp. 409-432.

[56] KRISTEN, C. (2008): "Primary School Choice and Ethnic School Segregation in German Elementary Schools”, European Sociological Review, vol. 24 (4), pp. 495-510.

[57] LEWIS, E. G. (2003): "Local Open Economies within the U.S.: How Do Industries Respond to Immigration?", Federal Reserve Bank of Philadelphia Working Paper No. 04-1.

[58] LEWIS, E. G. (2011): "Immigration, Skill Mix, and Capital-Skill Complementarity", Quarterly Journal of Economics, vol. 126 (2), pp. 1029-1069.

[59] LLULL, J. (2010): “Immigration, Wages, and Education: A Labour Market Equilibrium Structural Model”, Mimeo.

[60] MANACORDA, M.; MANNING, A. and J. WADSWORTH (2012): "The Impact of Immigration on the Structure of Wages: Theory and Evidence from Britain", Journal of the European Economic Association, vol. 10 (1), pp. 120-151.

[61] MOCETTI, S. and C. PORELLO (2010): "How Does Immigration Affect Native Internal Mobility? New Evidence from Italy", Regional Science and Urban Economics, vol. 40 (6), pp. 427-439.

[62] MUNSHI, K. (2003): "Networks in the Modern Economy: Mexican Migrants in the U.S. Labor Market”, Quarterly Journal of Economics, vol. 118 (2), pp. 549-599.

[63] OECD (multiple years): International Migration Outlook, OECD Publishing, Paris.

[64] OLNEY, W. (2013): "Immigration and Firm Expansion", Journal of Regional Science, vol. 53 (1), pp. 142-157.

[65] ORTEGA, F. and J. G. POLAVIEJA (2012): "Labor-market Exposure as a Determinant of Attitudes toward Immigration”, Labour Economics, vol. 19 (3), pp. 298-311.

[66] OTTAVIANO, G. I. P. and G. PERI (2007): "The Effects of Immigration on U.S. Wages and Rents: a General Equilibrium Approach", in Migration Impact Assessment: New Horizons, edited by Nijkamp, P., Poot, J. and M. Sahin, pp. 107-146, Edward Elgar Publishing Limited, Cheltenham.

[67] OTTAVIANO, G. I. P. and G. PERI (2012): "Rethinking the Effect of Immigration on Wages", Journal of the European Economic Association, vol. 10 (1), pp. 152-197.

[68] PERI, G. and C. SPARBER (2009): “Task Specialization, Immigration, and Wages", American Economic Journal: Applied Economics, vol. 1 (3), pp. 135-169.

[69] PERI, G. and C. SPARBER (2011): “Assessing Inherent Model Bias: An Application to Native Displacement in Response to Immigration", Journal of Urban Economics, vol. 69 (1), pp. 82-91.

[70] RODRÍGUEZ PLANAS, N. (2013): “Determinants of Immigrants' Cash-Welfare Benefits Intake in Spain”, International Journal of Manpower, vol. 34 (2), pp. 167 180.

[71] SAIZ, A. (2007): "Immigration and Housing Rents in American Cities", Journal of Urban Economics, vol. 61 (2), pp. 345-371. 
[72] SANROMÁ, E.; RAMOS, R. and H. SIMÓN (2009): “Immigrant Wages in the Spanish Labour Market: Does the Origin of Human Capital Matter?", IZA Discussion Paper No. 4157.

[73] SCHNEEWEIS, N. (2013): "Immigrant Concentration in Schools: Consequences for Native and Migrant Students", IZA Discussion Papers No. 7230.

[74] SIMÓN, H.; SANROMÁ, E. and R. RAMOS (2008): "Labour Segregation and Immigrant and Native-born Wage Distributions in Spain: an Analysis Using Matched Employer-employee Data", Spanish Economic Review, vol. 10, pp. 135-168.

[75] STEINHARDT, M. (2011): "The Wage Impact of Immigration in Germany - New Evidence for Skill Groups and Occupations", The B.E. Journal of Economic Analysis \& Policy, vol. 11 (1), pp. 1935-1682.

[76] TANAKA, R.; FARRÉ, L. and F. ORTEGA (2014): "Immigration, Naturalization, and the Future of Public Education", Mimeo CUNY.

[77] UNITED NATIONS (2009): "Trends in International Migrant Stock: The 2008 Revision" (United Nations database, POP/DB/MIG/Stock/Rev.2008), Department of Economic and Social Affairs.

[78] UNITED NATIONS (2013): “Trends in International Migrant Stock: The 2013 Revision" (United Nations database, POP/DB/MIG/Stock/Rev.2013), Department of Economic and Social Affairs.

[79] WOZNIAK, A. and T. MURRAY (2012): “Timing is Everything: Short-run Population Impacts of Immigration in US Cities", Journal of Urban Economics, vol. 72 (1), pp. 6078.

[80] ZINOVYEVA, N.; FELGUEROSO, F. and P. VAZQUEZ (2014): "Immigration and Student Achievement in Spain: Evidence from PISA", SERIEs, vol. 5 (1), pp 25-60. 